\title{
ARTICLE
}

\section{Environmental factors affecting structure and spatial patterns of larval fish assemblages in the southern Gulf of Mexico}

Factores ambientales que afectan la estructura y patrones espaciales de las asociaciones de larvas de peces en el sur del Golfo de México

\section{César Flores-Coto ${ }^{1}$, Laura Sanvicente-Añorve ${ }^{1}$, Faustino Zavala-García ${ }^{1}$, Jorge Zavala-Hidalgo ${ }^{2}$ and Rene Funes-Rodríguez ${ }^{3}$}

\begin{abstract}
${ }^{1}$ Instituto de Ciencias del Mar y Limnología, Universidad Nacional Autónoma de México. Av. Universidad 3000, Apartado Postal 04510, Ciudad Universitaria, México, D.F., México. coto@cmarl.unam.mx

${ }^{2}$ Centro de Ciencias de la Atmósfera, Universidad Nacional Autónoma de México. Av. Universidad 3000, Ciudad Universitaria, México, D.F., México

${ }^{3}$ Instituto Politécnico Nacional, Centro Interdisciplinario de Ciencia Marinas. Av IPN, Col. Playa Palo de Sta. Rita, La Paz, Baja California Sur, México

Resumen.- Se estudiaron los factores ambientales que afectan las asociaciones de larvas de peces en el sur del Golfo de México. Las muestras se obtuvieron con redes Bongo de superficie a $200 \mathrm{~m}$, en 46 estaciones, en primavera 2006 . A cada taxón de larvas se le asignó el hábitat de sus adultos. Las asociaciones de larvas se definieron por el índice de Bray-Curtis. Se registró un total de 182 taxones, la mayoría oceánicos, de plataforma media y arrecifales. Se definieron 3 comunidades, Yucatán (YA), Tabasco-Campeche (TCA) y Oceánica (OA). YA se ubicó sobre el Banco de Campeche, en la amplia plataforma de Yucatán, donde el proceso hidrodinámico más importante es una rama de la corriente de Yucatán. TCA ocupó la plataforma de Tabasco y suroeste de la plataforma de Campeche, caracterizada por la descarga de aguas continentales. OA ocupó el área oceánica de la Bahía de Campeche, donde el proceso hidrodinámico dominante es un giro ciclónico casi permanente. Como resultado de diferentes hechos hidrográficos, sean corrientes oceánicas, presencia de giros o descargas de aguas dulces, y la topografía; la plataforma de Tabasco, el Banco de Campeche (plataforma de Yucatán) y la Bahía de Campeche constituyen regiones con escenarios ambientales claramente contrastantes. La distribución geográfica de las 3 asociaciones de larvas se ajusta bien con estas 3 áreas de diferente hidrodinámica. La estructura y distribución espacial de las asociaciones de larvas está determinada en primer lugar por el hábitat y áreas de desove de sus adultos, siendo después modulada por las forzantes hidrográficas que caracterizan cada área.
\end{abstract}

Palabras clave: Asociaciones de larvas de peces, hidrodinámica, Golfo de México

\begin{abstract}
The environmental factors that affect larval fish assemblages in the southern Gulf of Mexico were studied. Samples were collected with a Bongo net from the surface to a depth of $200 \mathrm{~m}$, at 46 sampling stations, during spring 2006 . The adult habitat was assigned to each larval fish taxon. Larval assemblages were defined by the Bray-Curtis index. A total of 182 taxa were found, of which most were oceanic, mid shelf and reef. Three assemblages were defined: Yucatan (YA), TabascoCampeche (TCA) and Oceanic (OA). The YA was located on the Campeche Bank, the wide Yucatan shelf where the most important hydrodynamic processes is a branch of Yucatan current. The TCA occupied the shelf of Tabasco and the southwestern shelf of Campeche, characterized by the continental freshwater discharge. The OA occupied the oceanic area of Campeche Bay, where the dominant hydrodynamic process is an almost permanent cyclonic gyre. As a result of the different hydrographic features, which are ocean currents, presence of gyres, freshwater discharge, and the topography; the Tabasco shelf, Campeche Bank (Yucatan shelf) and Campeche Bay constitute different regions. They are regions with clearly contrasting environmental scenarios. The geographic distribution of the 3 assemblages fitted well with these 3 hydrodynamically different areas. The structure and spatial distribution of the larval assemblages was determined first by the habitat of the adults and the spawning areas, and then being modulated by the hydrographic features that characterize each area.
\end{abstract}

Key words: Larval fish assemblages, hydrodynamics, Gulf of Mexico

\section{INTRODUCTION}

The composition, abundance and distribution of larval fish assemblages in any area depend first on biological factors such as the structure of adult fish communities, which in turn is conditioned by the characteristics of the habitat and especially on the species reproductive habits that are related to the location and time of spawning, 
resulting from an evolutionary process aiming at maximizing the survival of the offspring; and the hydrodynamics of the area that constitute a preponderant factor for the planktonic stages, eggs and larvae.

The southern Gulf of Mexico (Campeche Bank and Campeche Bay) presents a great variety of fish habitats that include open ocean areas, continental shelves that receive freshwater discharges, and estuaries and coastal lagoons that provide nursery areas for many fish species.

To this variety of habitats one must add that the hydrodynamics of the region are dominated by several hydrodynamic processes that generate different hydrographic scenarios. Several regions have been identified: Campeche Bank, Veracruz shelf, Tabasco and Campeche shelves and Campeche Bay.

Campeche Bank is a wide shelf north and northwest of the Yucatan peninsula, basically a calcareous area with its western boundary at the Campeche canyon; here the main predominant feature is a westward and southwestward circulation along the northern and western littorals of the peninsula, respectively, throughout the year as result of a branch of the Yucatan current that flows along the Campeche Bank carrying water from the upwelling off Cabo Catoche (Merino 1997, Portilla-Casillas et al. 2003, Zavala-Hidalgo et al. 2003). In the Campeche Bank there are series of small reefs, some of which have formed islands, and the coastal lagoons adjacent to this shelf have no freshwater discharges or any connection with rivers.

Other region is the Tabasco and Campeche shelf. The Veracruz shelf presents a seasonal circulation that moves southeast from September to March and northwest from May to August, consequently the circulation on the Tabasco and Campeche shelves is affected by the confluence of the northerly current coming from the Campeche Bank and the southerly current coming from the Veracruz shelf during Autumn-Winter (Zavala-Hidalgo et al. 2003). In the area the most important hydrodynamic process is the freshwater discharge from the main riverlagoon systems, among which the most important rivers are the Grijalva, Usumacinta, San Pedro y San Pablo and Coatzacoalcos along the Tabasco and southern Veracruz coasts.

A third region is Campeche Bay, which includes the region south of $22^{\circ} \mathrm{N}$ but excludes the continental shelves, the eastern boundary at the Campeche canyon, the region presents as the main hydrographic feature a semi- permanent cyclonic circulation that covers mainly the southwestern area and also the narrow Veracruz shelf and the most external part of the Campeche and Yucatan shelves (Padilla et al. 1990, Salas de León et al. 1992, Signoret et al. 2006), as well as a weak northward current in its western region, as well as some intermittent anticyclones (Pérez-Brunius et al. 2013).

These regions are defined by the forcing that affects them. The winds have a seasonal component in the western Gulf, mostly with northeasters in Autumn-Winter and southeasters in the late Spring and Summer. These winds are the main forcing of the Veracruz shelf currents. On the Campeche Bank, the winds are easterlies throughout the year and are the main cause of the circulation pattern. The cyclonic circulation in Campeche Bay has being attributed to wind stress curl, which is mainly positive in the area, but also to the northern Gulf of Mexico eddies when they interact with the continental slope and move southward (Sutyrin et al. 2003, Romanou et al. 2004, Vázquez de la Cerda et al. 2005).

These and other differences have led to a regionalization of the Gulf of Mexico that has considered a variety of criteria including the sedimentary geology (Araujo-Mendieta et al. 2003), irradiance (Callejas-Jiménez et al. 2012), chlorophyll concentration (Salmerón-García et al. 2011) and hydrological processes (Zavala-Hidalgo \& Fernández-Eguiarte 2006).

To date, most studies on the ichthyoplankton in the southern Gulf of Mexico have focused on the region south of $21^{\circ} \mathrm{N}$, with many studies restricted to the continental shelves of Tabasco and Campeche (FloresCoto et al. 1988, 2009). Regarding the ichthyoplankton of the Yucatan shelf, there is scarce information (SánchezVelasco \& Flores-Coto 1994, Falfán-Vázquez et al. 2008). The distribution of larvae in the studied area reflects the reproductive strategies of the adults (Flores-Coto et al. 1993, Sanvicente-Añorve et al. 1998). The part played by the main hydrological factors that affect this distribution, such as the freshwater discharges and the main circulation patterns, has also been analyzed (Sanvicente-Añorve et al. 1998, Salas de Leon et al. 1998). However, no previous study has included the whole southern Gulf of Mexico to obtain an integral vision of the dominant physical conditions and their effect on the formation of fish larvae communities in the area. Therefore, the goal of this study was to determine the biological and environmental factors that affect larval fish assemblages in the southern Gulf of Mexico. 


\section{Materials AND Methods}

The study area lies in the southern Gulf of Mexico between $18^{\circ}-23^{\circ} \mathrm{N}$ and $87^{\circ}-97^{\circ} \mathrm{W}$ (Fig. 1). Biological and physical parameters were collected from May 19 to June 18 2006, aboard the research vessel 'Justo Sierra' of the UNAM from a network of 46 stations.

Temperature and salinity data were recorded with a calibrated CTD probe (III/Woce) and turbidity (Nephelometric Turbidity Units) with a Hach Model 0220 nephelometer (APHA 2005). Abiotic data included in the analyses were those recorded from the surface to $200 \mathrm{~m}$ depth, or less depending of the depth of station.

Zooplankton samples were collected with $60 \mathrm{~cm}$ mouth diameter and 505 and $333 \mathrm{~mm}$ mesh size Bongo nets. The hauls were oblique from the surface to a maximum depth of $200 \mathrm{~m}$ or where the depth permitted, each following a circular trajectory at a speed of 2-3 knots. The volume of water filtered was calculated with calibrated flowmeters (General Oceanic, model 2030R) placed at the mouth of each net. Samples were fixed with $4 \%$ formaldehyde, buffered with sodium borate. Fish larvae were removed from the $505 \mathrm{~mm}$ mesh samples and identified to the species level when possible (Richards 2006, Fahay 2007). Larval abundance was standardized as number of larvae per $100 \mathrm{~m}^{3}$.

Bray-Curtis dissimilarity index was used to define species assemblages (Bray \& Curtis 1957) using data transformed to $\ln (x+1)$. A cluster was built from the dissimilarity matrix using the ANACOM program (De la Cruz 1994).

The main species of each assemblage were considered to perform a Canonical Correspondence Analysis, in order to elucidate the possible relationship between species distribution and physical environmental variables. To define the most important species was used $3 \%$ of the Importance Value index (IVI) which considers the sum of the abundance and frequency percentage, the final will yield a maximal value of $200 \%$.

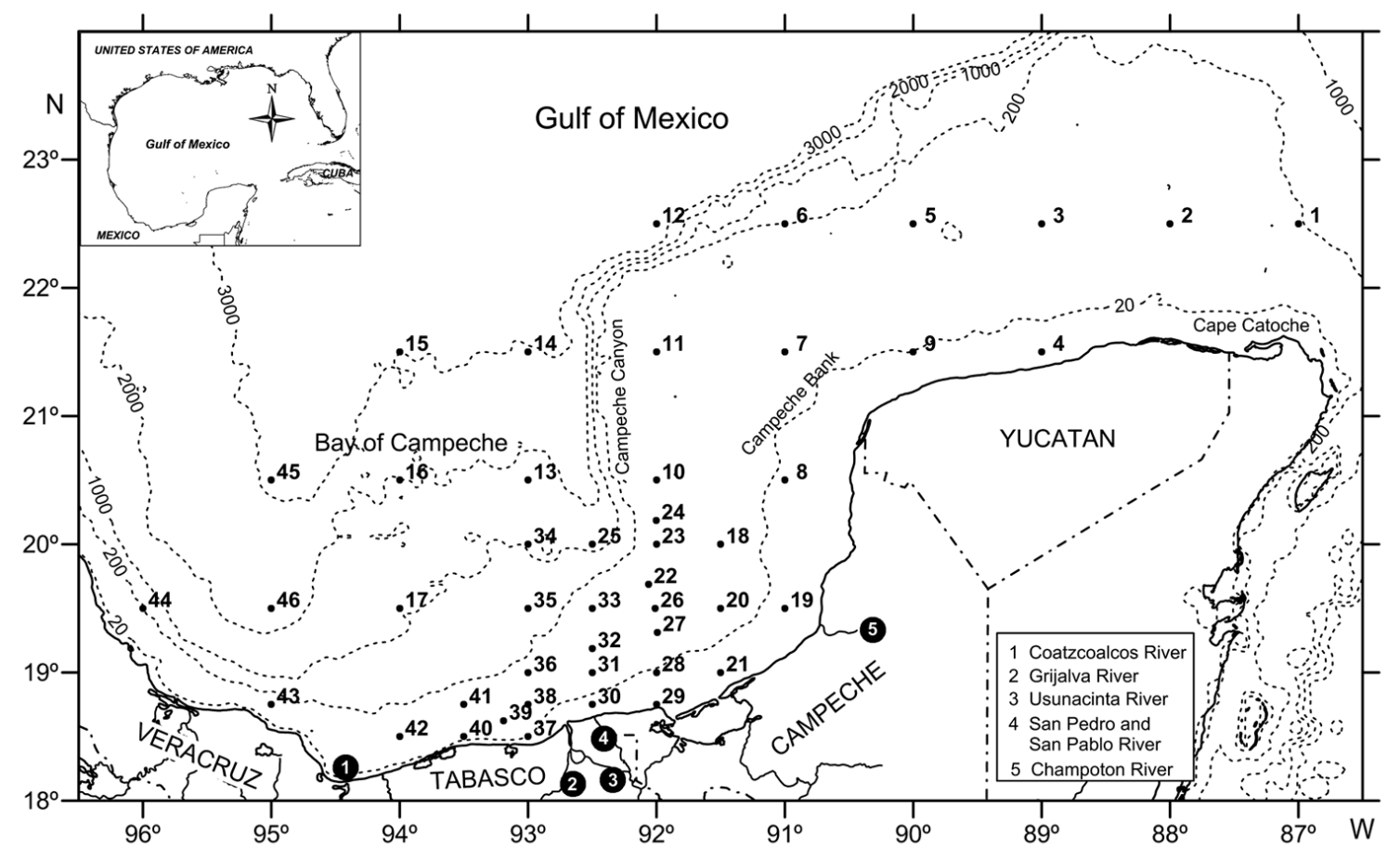

Figure 1. Study area and sampling stations / Área de estudio y estaciones de muestreo 
The habitat of the corresponding adults was assigned to each taxon in order to analyze the frequency and abundance of each type in the different assemblages, assuming that there would be differences essentially due to the hydrodynamics of the areas occupied by each assemblage. The habitats considered were neritic, oceanic, outer shelf, reef, mid shelf and coastal. Families (not genera or species) with a very wide distribution were including in the neritic habitat.

\section{Results}

\section{Hydrology ANd Circulation}

Salinity, temperature, and turbidity data as average of the $200 \mathrm{~m}$ surface layer or to the depth that the stations allowed it, were analyzed.

Salinity was very homogeneous throughout most the area, with values around 36.5 in the oceanic area, and 36.75 on the Campeche Bank. This homogeneousness is broken along the Tabasco and south of Veracruz coasts, off the main freshwater discharge systems were the lower salinities were recorded and small area with high values off the Champoton (Fig. 2A).
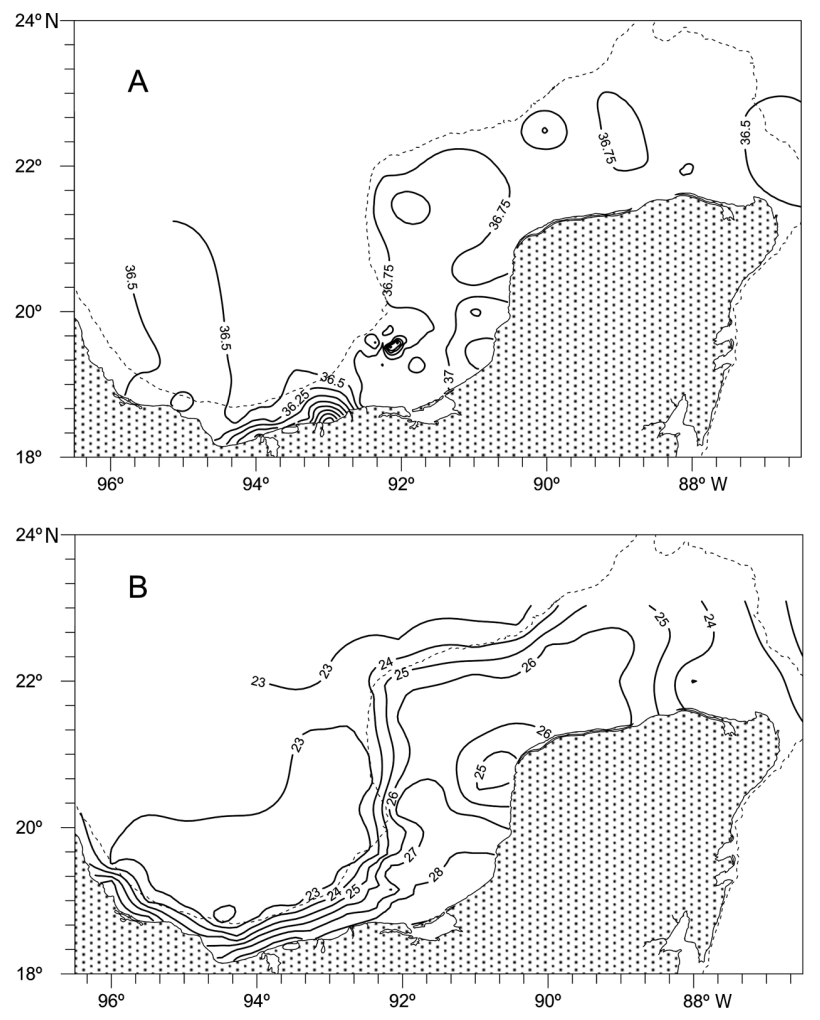

The lowers temperatures $\left(\sim 23^{\circ} \mathrm{C}\right)$ were recorded on oceanic area of Campeche bay; in contrast, higher values $\left(>26^{\circ} \mathrm{C}\right.$ ) occurred over the continental shelf from Veracruz to Campeche, particularly off the Términos Lagoon in a very wide area were the highest were recorded. On the Campeche Bank the temperature fluctuates between 24 and $26^{\circ} \mathrm{C}$, except on the most oriental portion (Fig. 2B).

Turbidity as well as the salinity was very homogeneous, with average values lower on the Yucatan shelf $(0.30)$ and greater on the Campeche-Tabasco shelf (0.44) off the main systems of continental water discharges, and intermediate values in the oceanic area (0.35) (Fig. 2C).

During the sampling period the surface geostrophic currents, estimated from altimetry products generated in the web site of the Colorado Center for Astrodynamics Research ${ }^{1}$, show that weak currents occurred, with a predominant minimum pattern in the Campeche Bay associated with a cyclonic circulation and a more intense cyclone (minimum) located in the southwestern region. North of the Bay of Campeche an anticyclone (hgh) is observed. The altimetry over the Campeche Bank is less reliable since is a shallow region and is expected to have a westward circulation as previous studies have reported (Zavala-Hidalgo et al. 2003, Enriquez et al. 2010) (Fig. 3).

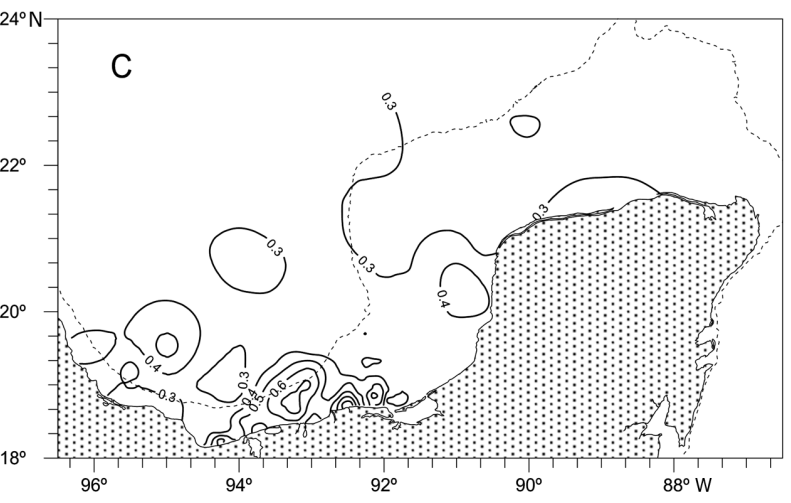

Figure 2. Salinity (A), temperature (B) and turbidity (C) isopleth in the $\mathbf{2 0 0} \mathbf{~ m}$ surface water layer / Salinidad (A), temperatura (B) y turbidez (C) isopletas en la capa de agua superficial de $200 \mathrm{~m}$

${ }^{1}<$ http://eddy.colorado.edu/ccar/ssh/nrt_gom_grid_viewer> 


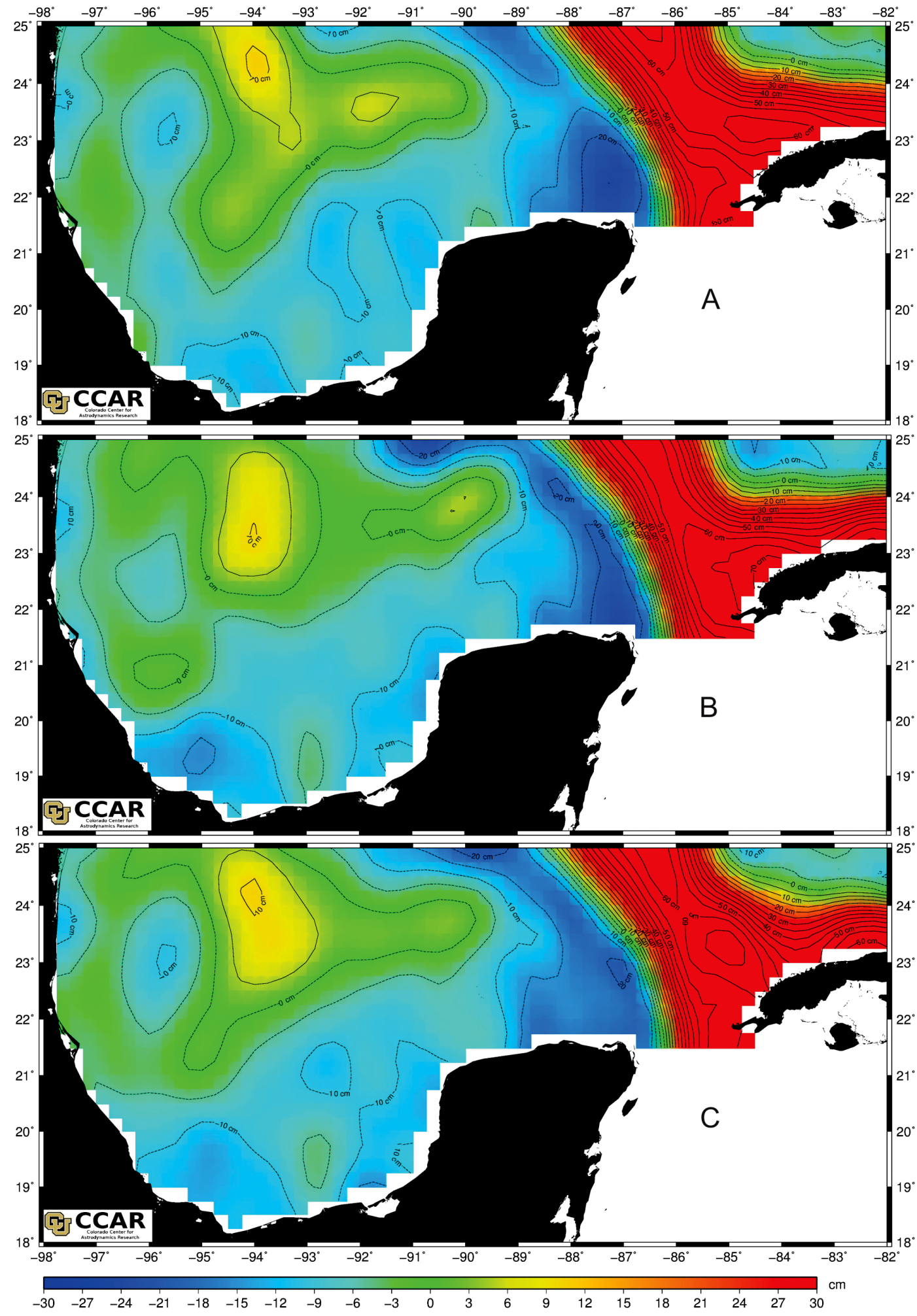

Figure 3. Mesoscale altimetry of the Gulf of Mexico. A) May 15, 2006, B) May 30, 2006, C) June 15, 2006 / Altimetría a mesoescala del Golfo de México. A) Mayo 15, 2006, B) Mayo 30, 2006, C) Junio 15, 2006 


\section{LARVAL COMPOSITION}

A total of 182 taxa were recorded (Table 1) of which, considering the habitat of their adults, most were oceanic $(29.6 \%)$, mid shelf $(26.3 \%)$ and reef $(25.2 \%)$ species and the others were coastal $(10.4 \%)$, neritic $(4.4 \%)$ and outer shelf $(3.3 \%)$ species.

The Bray-Curtis dissimilarity analysis defined 3 assemblages (Figs. 4 and 5): Yucatan assemblage (YA), Tabasco-Campeche assemblage (TCA) and Oceanic assemblage (OA), with geographic distributions that fitted well with 3 different hydrodynamic areas.

The Yucatan assemblage was located in the Campeche Bank, the wide Yucatan shelf with its western boundary at the Campeche canyon. The Tabasco-Campeche assemblage occupied the Tabasco and Campeche continental shelves. The Oceanic assemblage occupied the oceanic area of Campeche Bay with its southern boundary at the continental shelf and its eastern boundary at the Campeche canyon.
The greatest number of taxa was 113 for the TCA and the lowest was 75 for the YA, while 91 taxa were recorded for the OA. The average densities were 103.16, 26.76 and 8.15 ind. $100 \mathrm{~m}^{-3}$, respectively (Fig. 5A).

The results indicate that the percentages for the oceanic, mid shelf and reef habitats for the identified fish larvae taxa were very similar, however, the percentages in the different assemblages varied in relation to the area that each occupied, indicating a predominance of one type of habitat for each (Fig. 6).

Of the 75 taxa recorded for the YA, most corresponded to organisms of reef $(36.5 \%)$ and mid shelf $(33.8 \%)$ habitats (Fig. 6A), with 19 exclusive taxa of which $37 \%$ were reef organisms (Fig. 6B).

Of the 91 taxa recorded for the OA, more than half (53\%) were oceanic and $20 \%$ were mid shelf organisms (Fig. 6A), with 48 exclusive taxa of which $83.3 \%$ were oceanic organisms. This assemblage presented the lesser density of organisms (Fig. 6B).

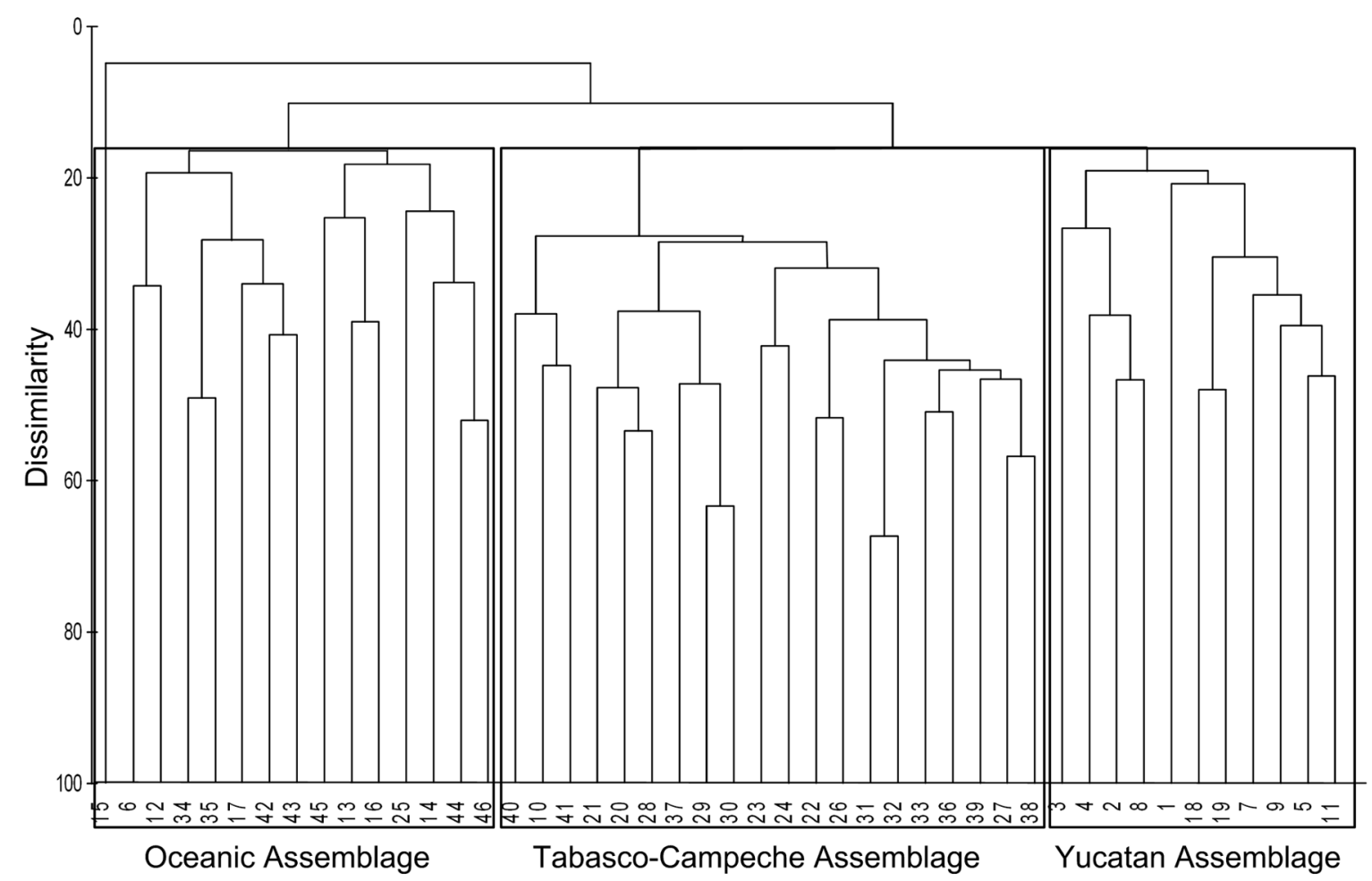

Figure 4. Dissimilarity dendrogram, defining 3 assemblages / Dendrograma de disimilitud, definiendo 3 asociaciones 
Of the 113 taxa recorded for the TCA, most were mid shelf $(36.6 \%)$ and reef $(34.0 \%)$ organisms (Fig. 6A), with 45 exclusive taxa of which more than $82 \%$ were mid shelf, coastal and reef organisms (Fig. 6B).

The most abundant and exclusive species and genera of each assemblage agree the area in which they were found, thus, the most abundant species in the OA were Notolichnus valdiviae Brauer, 1904, Benthosema suborbitale Gilbert, 1913 and Diaphus spp. of the oceanic habitat, together with Bregmaceros cantori, Milliken \& Houde, 1984 and the most abundant exclusive species, apart from the first two species stated above, were Symbolophorus rufinus Tåning, 1928, Hygophum reinhartii Lütken, 1892 and Hygophum hygomii Lütken, 1892 of the oceanic habitat.

The dominant organisms in the YA, located on the calcareous shelves of Yucatan and Campeche, included the reef species Pseudogramma gregoryi Breder, 1927 and Prionotus spp., the mid shelf species Decapterus punctatus Cuvier, 1829 and Lutjanus campechanus Poey, 1860 and the coastal species Stephanolepis spp. and Chloroscombrus chrysurus Linnaeus, 1766. Among the most abundant exclusive taxa, apart from Stephanolepis and $P$. gregoryi already mentioned, were the reef species Diplogramus pauciradiatus Gill, 1865 and the mid shelf species Decapterus spp.

The dominant organisms in the TCA were the mid shelf species B. cantori, Symphurus plagiusa Linnaeus, 1766 and Syacium gunteri Ginsburg, 1933 and the coastal species $C$. chrysurus, apart from Anchoa spp. that has a wide distribution. Among the abundant exclusive taxa, the dominant species were the mid shelf Diplectrum spp. and Selene setapinnis Mitchill, 1815, the coastal Cynoscion arenarius Ginsburg, 1930 and Micropogonias spp., and the reef-dwelling Balistes capriscus Gmelin, 1789.

Of the 182 taxa, only 25 were present in the 3 assemblages, which is less than $14 \%$. Only 3 oceanic taxa were shared by the YA and the OA. The OA and the TCA shared 15 taxa, most of which were oceanic and mid shelf organisms. The greatest number of shared taxa (28) occurred in the YA and the TCA, most of which were reef, mid shelf and coastal organisms, and none oceanic as may be expected.

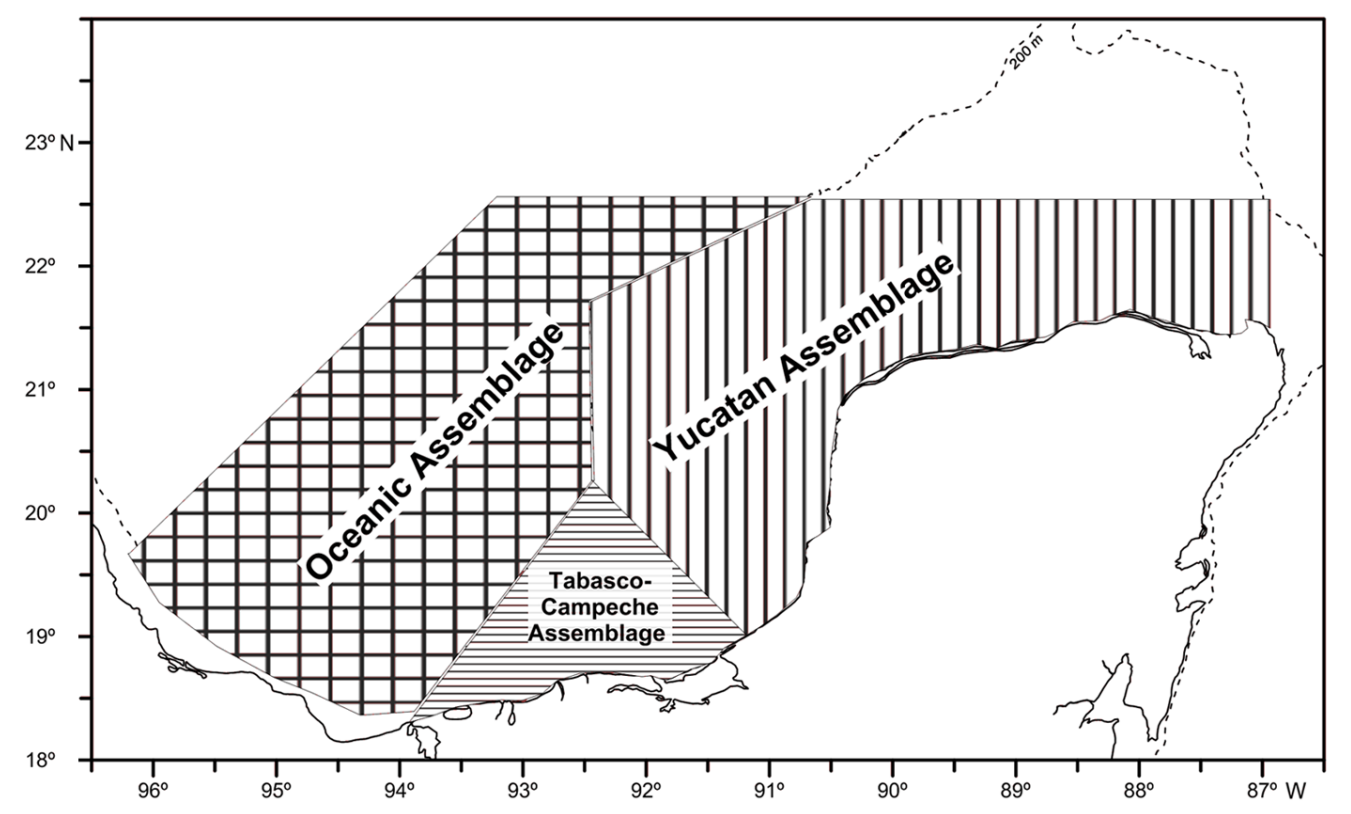

Figure 5. Geographical location of the areas occupied by the assemblages / Ubicación geográfica de las zonas ocupadas por las asociaciones 
A

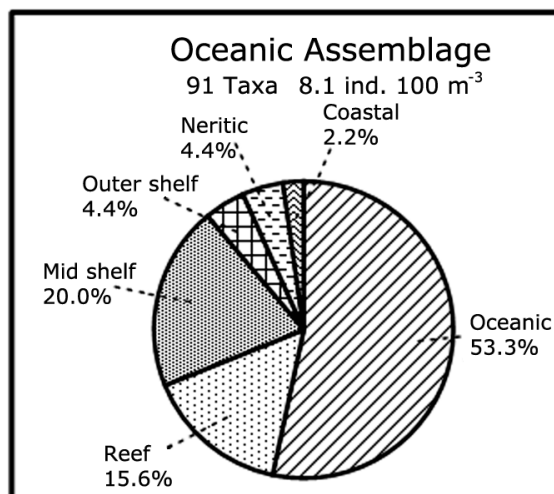

Tabasco-Campeche Assemblage 113 Taxa 103.1 ind. $100 \mathrm{~m}^{-3}$ Coastal Oceanic
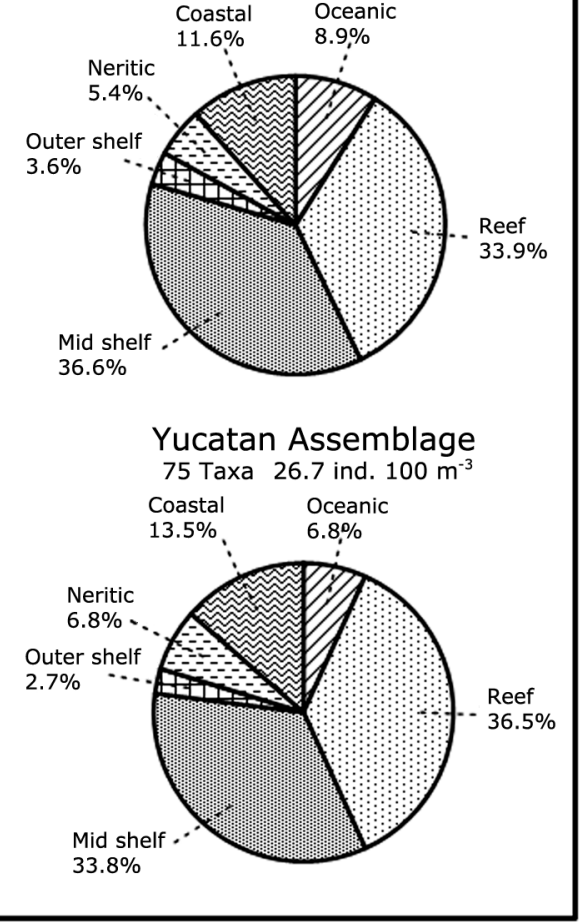

B

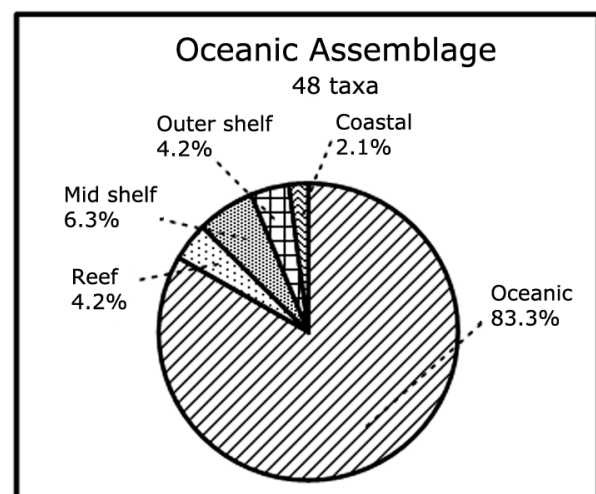

Tabasco-Campeche Assemblage 45 Taxa

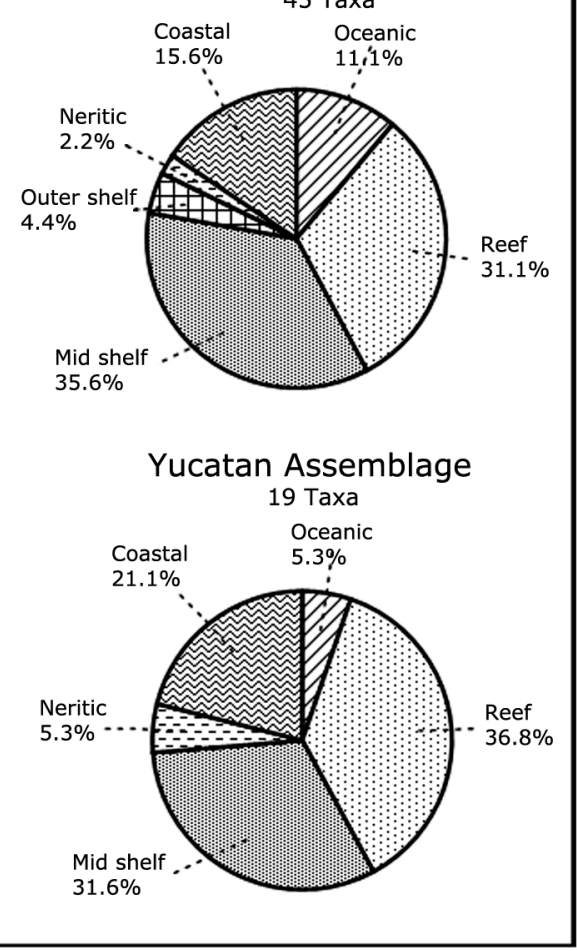

Figure 6. Proportion of habitats represented in each assemblage: A) all taxa, B) taxa exclusive of each assemblage / Proporción de hábitats representados en cada asociación: A) todos los taxones, B) taxones exclusivos de cada asociación 


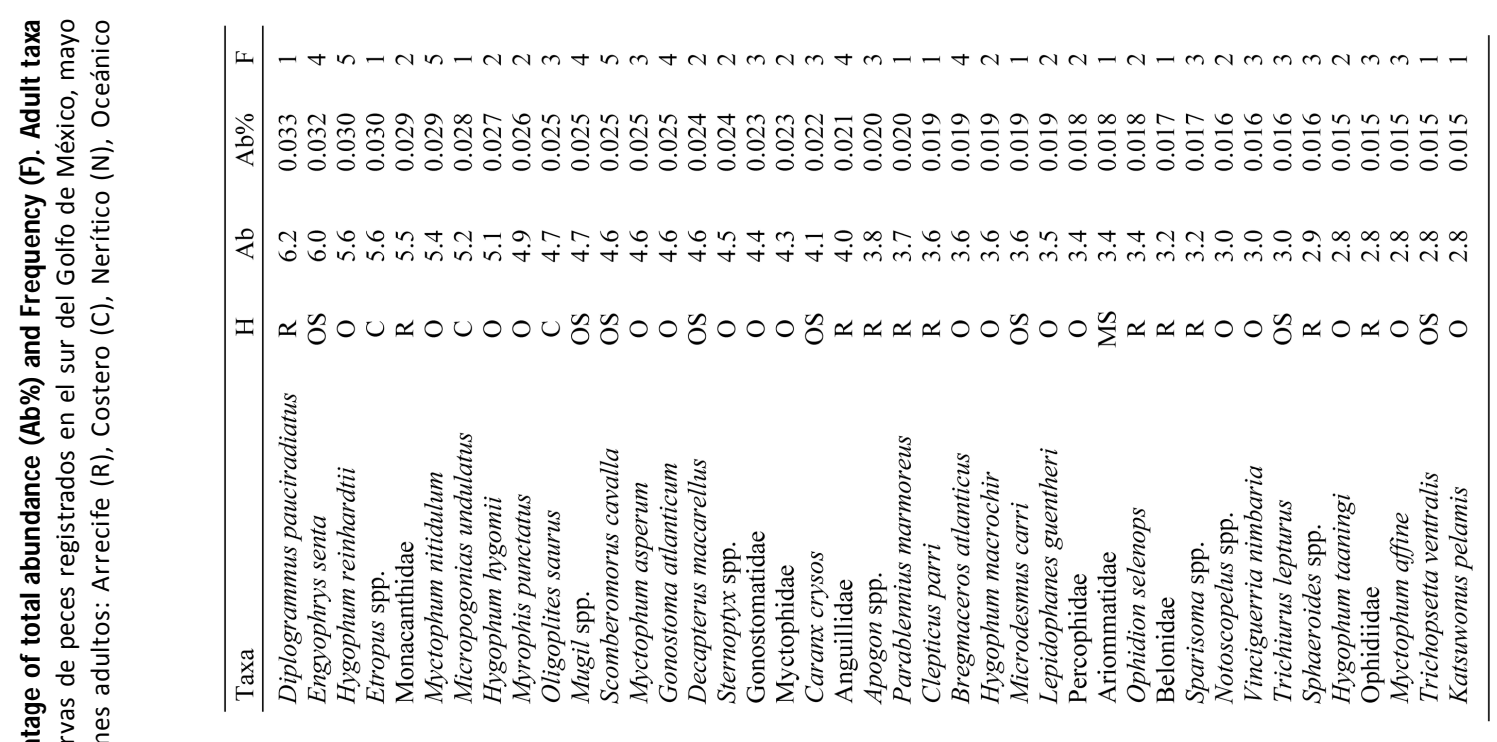

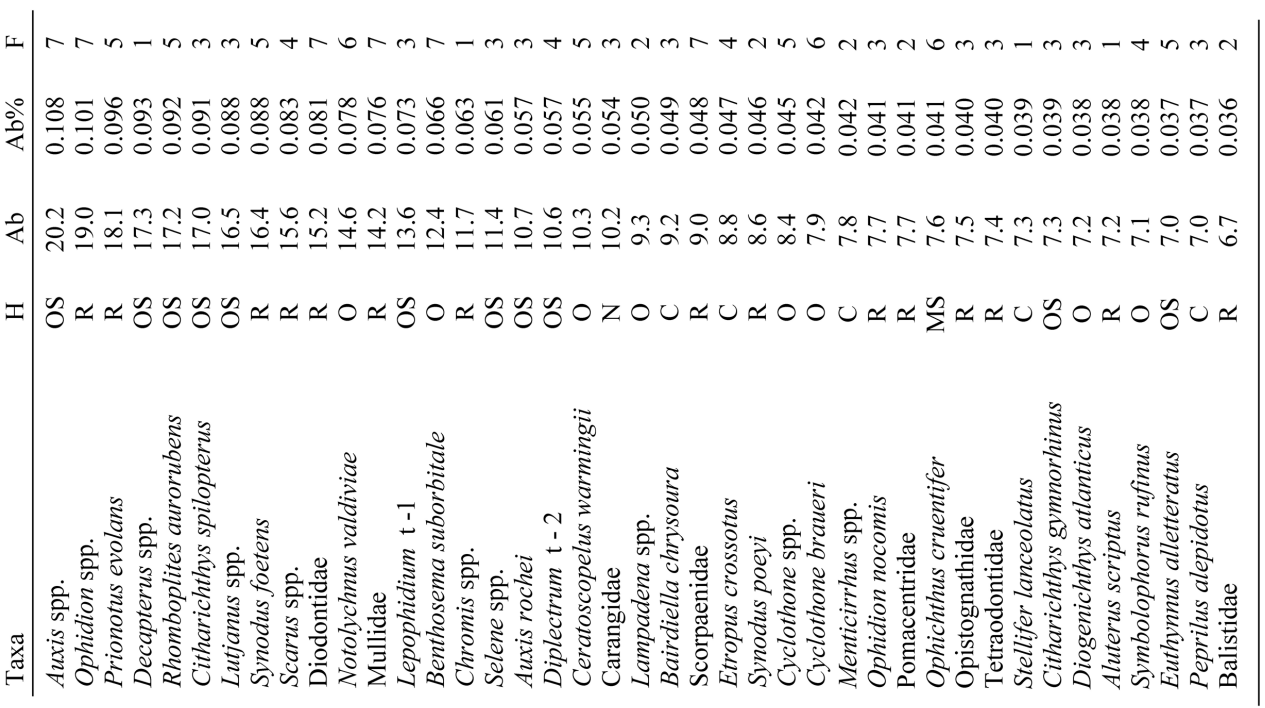

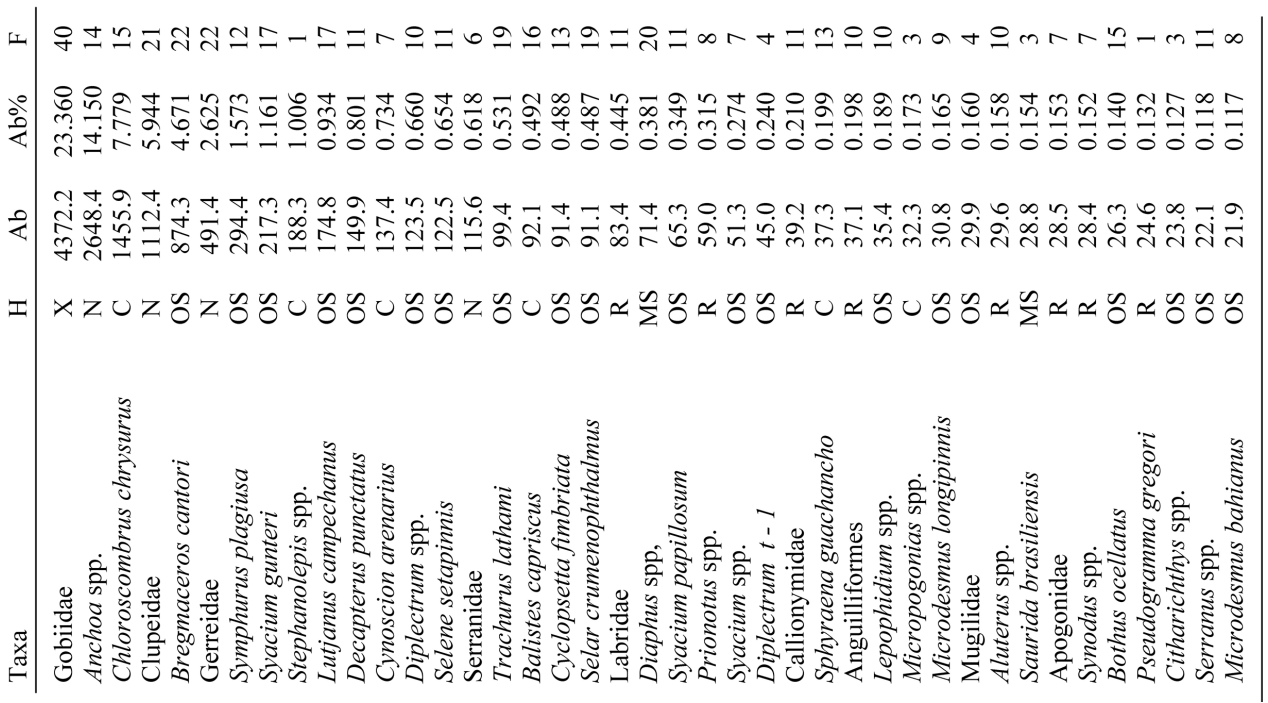


Table 1. Continued / Continuación

\begin{tabular}{|c|c|c|c|c|}
\hline Taxa & $\mathrm{H}$ & $\mathrm{Ab}$ & $\mathrm{Ab} \%$ & $\mathrm{~F}$ \\
\hline Vinciguerria poweriae & $\mathrm{O}$ & 2.7 & 0.014 & 2 \\
\hline Heteropriacanthus cruentatus & $\mathrm{R}$ & 2.5 & 0.014 & 1 \\
\hline Cynoscion nothus & $\mathrm{C}$ & 2.4 & 0.013 & 2 \\
\hline Paralepididae & $\mathrm{O}$ & 2.2 & 0.012 & 2 \\
\hline Auxis thazard & OS & 2.1 & 0.011 & 1 \\
\hline Citharichthys arctifrons & OS & 2.0 & 0.011 & 2 \\
\hline Epinephelus spp. & OS & 1.9 & 0.010 & 2 \\
\hline Scombridae & $\mathrm{N}$ & 1.9 & 0.010 & 2 \\
\hline Lestidiops affinis & $\mathrm{O}$ & 1.9 & 0.010 & 2 \\
\hline Thunnus spp. & $\mathrm{O}$ & 1.9 & 0.010 & 2 \\
\hline Myctophum selenops & $\mathrm{O}$ & 1.8 & 0.009 & 2 \\
\hline Caranx spp. & OS & 1.7 & 0.009 & 1 \\
\hline Sphyraena spp. & $\mathrm{C}$ & 1.7 & 0.009 & 1 \\
\hline Fistularidae & $\mathrm{N}$ & 1.7 & 0.009 & 2 \\
\hline Polynemidae & $\mathrm{C}$ & 1.6 & 0.009 & 1 \\
\hline Symphurus spp. & OS & 1.6 & 0.009 & 1 \\
\hline Vinciguerria attenuata & $\mathrm{O}$ & 1.6 & 0.008 & 1 \\
\hline Chauliodus sloani & $\mathrm{O}$ & 1.6 & 0.008 & 1 \\
\hline Aluterus schoepfii & $\mathrm{R}$ & 1.5 & 0.008 & 1 \\
\hline Ostraciidae & $\mathrm{R}$ & 1.5 & 0.008 & 1 \\
\hline Myctophum spp. & $\mathrm{O}$ & 1.4 & 0.007 & 1 \\
\hline Cerdale floridana & $\mathrm{R}$ & 1.2 & 0.007 & 1 \\
\hline Scombreromorus regalis & OS & 1.2 & 0.007 & 1 \\
\hline Chasmodes spp. & $\mathrm{C}$ & 1.2 & 0.006 & 1 \\
\hline Bythitidae & $\mathrm{R}$ & 1.2 & 0.006 & 1 \\
\hline Valenciennellus tripunctulatus & $\mathrm{O}$ & 1.2 & 0.006 & 1 \\
\hline Liopropoma spp. & OS & 1.1 & 0.006 & 2 \\
\hline Caulophrynidae & $\mathrm{O}$ & 1.1 & 0.006 & 1 \\
\hline Exocoetidae & $\mathrm{N}$ & 1.1 & 0.006 & 1 \\
\hline Carapidae & OS & 1.1 & 0.006 & 1 \\
\hline
\end{tabular}

With 37 taxa as resulting of $3 \%$ of IVI, a CCA was performed. The distribution of taxa in relation to the axes show 3 groups which nearly correspond to the 3 assemblages taxa, aside of those which share among them (Fig. 7). The CTA taxa were related with high temperature and turbidity, as $S$. setapinis, B, crapisicus, $S$. guachancho, S. plagiusa, C. arenarius, among others. In contrast, the OA taxa appear related to low temperature and turbidity as B. atlanticus, $M$. asperum, $H$. reinhartii, B. suborbitale, G. atlanticum, S. rufinus, among others. The YA taxa seem to be more related with low turbidity and high salinity, as P. gregoryi, D. punctatus, Serranus spp., and L. campechanus (Fig. 7).

\section{Discussion}

\section{Assemblages AND Regionalization}

The 3 fish larvae assemblages defined by the similarity analysis (YA, TCA and OA) showed a geographic

\begin{tabular}{lcccc}
\hline Taxa & $\mathrm{H}$ & $\mathrm{Ab}$ & $\mathrm{Ab} \%$ & $\mathrm{~F}$ \\
\hline Ogcocephalidae & $\mathrm{R}$ & 1.0 & 0.006 & 1 \\
Rypticus spp. & $\mathrm{R}$ & 1.0 & 0.006 & 1 \\
Scomberomorus maculatus & $\mathrm{OS}$ & 1.0 & 0.006 & 1 \\
Maurolicus muelleri & $\mathrm{O}$ & 1.0 & 0.005 & 1 \\
Haemulidae & $\mathrm{R}$ & 1.0 & 0.005 & 1 \\
Melanostomiidae & $\mathrm{O}$ & 1.0 & 0.005 & 1 \\
Etropus microstomus & $\mathrm{C}$ & 1.0 & 0.005 & 1 \\
Pollichthys mauli & $\mathrm{O}$ & 1.0 & 0.005 & 1 \\
Leptostomias spp. & $\mathrm{O}$ & 1.0 & 0.005 & 1 \\
Coryphaena spp. & $\mathrm{O}$ & 1.0 & 0.005 & 1 \\
Albuliformes & $\mathrm{R}$ & 1.0 & 0.005 & 1 \\
Gonostoma elongatum & $\mathrm{O}$ & 0.9 & 0.005 & 1 \\
Vinciguerria spp. & $\mathrm{O}$ & 0.9 & 0.005 & 1 \\
Idiacanthus fasciola & $\mathrm{O}$ & 0.9 & 0.005 & 1 \\
Centrobranchus nigroocellatus & $\mathrm{O}$ & 0.9 & 0.005 & 1 \\
Acropomatidae & $\mathrm{MS}$ & 0.9 & 0.005 & 1 \\
Ophidion marginatum & $\mathrm{R}$ & 0.9 & 0.005 & 1 \\
Coryphaena equiselis & $\mathrm{O}$ & 0.9 & 0.005 & 1 \\
Pontinus spp. & $\mathrm{R}$ & 0.9 & 0.005 & 1 \\
Hygophum spp. & $\mathrm{O}$ & 0.9 & 0.005 & 1 \\
Canthigaster rostrata & $\mathrm{R}$ & 0.8 & 0.005 & 1 \\
Scopelarchus spp. & $\mathrm{O}$ & 0.8 & 0.004 & 1 \\
Lepidophanes spp. & $\mathrm{O}$ & 0.8 & 0.004 & 1 \\
Scopelarchus analis & $\mathrm{O}$ & 0.8 & 0.004 & 1 \\
Macroparalepis affinis & $\mathrm{O}$ & 0.8 & 0.004 & 1 \\
Macroparalepis brevis & $\mathrm{O}$ & 0.8 & 0.004 & 1 \\
Diaphus rafinesquii & $\mathrm{MS}$ & 0.8 & 0.004 & 1 \\
Argyropelecus spp. & $\mathrm{O}$ & 0.8 & 0.004 & 1 \\
Myctophum obtusirostre & $\mathrm{O}$ & 0.8 & 0.004 & 1 \\
\hline & & & & \\
\hline
\end{tabular}

distribution that fitted well with the 3 different areas resulting from hydrological processes (Zavala-Hidalgo \& Fernández-Eguiarte 2006), which it could be mean that, together with the biological aspect that corresponds to the habitat of the adults and their reproductive habits, the assemblages were strongly affected by the dominant hydrodynamics in each area, as occur in other parts of the world (Alemany et al. 2006, Sabatés et al. 2007).

The CCA helps to support this idea, since it allows to distinguish groups of taxa affected to a greater or lesser extent by some of the hydrographic parameters analyzed; therefore, OA taxa are related to low temperatures, which are commonly recorded in the oceanic area of the Campeche Bay and contrast with those of the adjacent continental shelf (Monreal-Gómez et al. 1992). On the other hand, the taxa of the TCA appear linked at high temperatures and especially to high turbidity which makes sense if we know that the location of this assemblage is exactly off the main download area of inland waters 


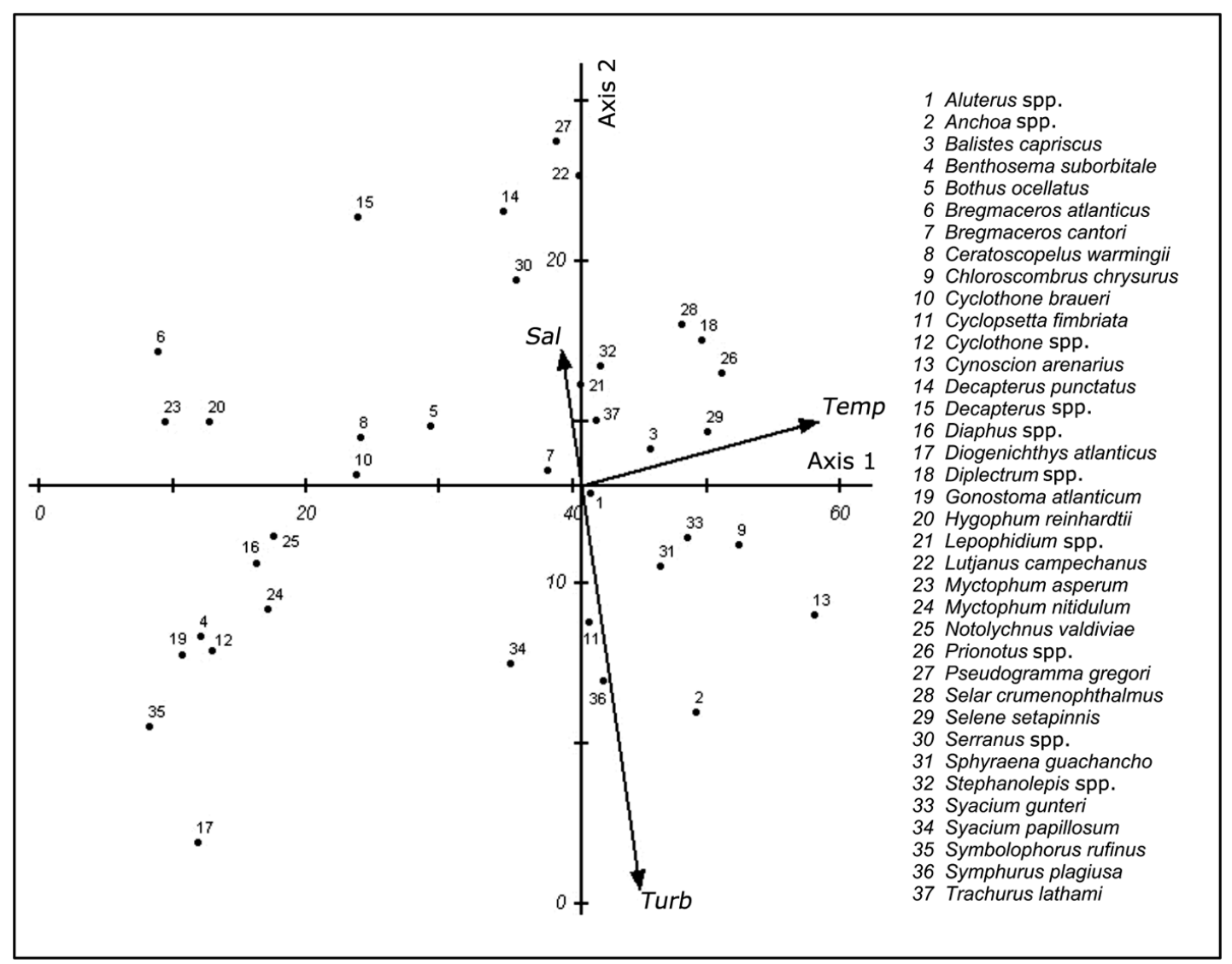

Figure 7. Canonical correspondence analysis biplot of the most abundant and frequent taxa (IVI >3\%) from the Oceanic, Tabasco-Campeche and Yucatan assemblages, defined by dissimilarity analysis / Análisis Canónico de Correspondencia de los taxones más abundantes y frecuentes (IVI >3\%) de las asociaciones Oceánica, Tabasco-Campeche y Yucatán,

carrying large amount of sediments and organic matter, which consequently creates areas of low concentration of oxygen, as showed by Padilla-Pilotze et al. (1990). Taxa of YA appear related to high salinity and low turbidity, which seems a logical condition if we know that the waters covering the Yucatan shelf are a branch of the Yucatan current with more oceanic that coastal character (Merino 1997, Mühling et al. 2013)

The composition and distribution of fish larvae species in Campeche Bank and Campeche Bay depend first on the habitat and the reproductive strategies of the adults, which include the spawning areas (Flores-Coto et al. 1988, 1993, Sanvicente-Añorve et al. 2000, Espinosa-Fuentes $\&$ Flores-Coto 2004). This is a general fact worldwide
(Rakocinski et al. 1996, Sabatés \& Olivar 1996, Miller 2002, Marancik et al. 2005, Sabatés et al. 2007), for which the complement establishing differences among the assemblages are the factors that determine the hydrodynamics of each region.

These and other differences have led to a regionalization of the Gulf of Mexico that has considered a variety of criteria including the sedimentary geology (Araujo-Mendieta et al. 2003), irradiance (Callejas-Jiménez et al. 2012), chlorophyll concentration (Salmerón-García et al. 2011) and hydrodynamical processes (ZavalaHidalgo \& Fernández-Eguiarte 2006). 
However, the best fit for the 3 assemblages corresponded closely to areas 2, 3 and 6 of the regionalization proposed by Zavala-Hidalgo \& FernándezEguiarte (2006) (Fig. 8), though there is also a close correspondence between the physiographic provinces (Araujo-Mendieta et al. 2003) formed over thousands of years and the assemblages recorded here. This must also mean that the hydrographic factors that determine the distribution patterns of fish larvae have prevailed over thousands of years.

\section{BOUNDARIES AND INTERACTIONS OF THE AREAS OF THE ASSEMBLAGES}

The interaction that takes place among areas makes their geographic boundaries dynamic, as may be seen in the records of oceanic organisms on the Yucatan, Campeche and Tabasco shelves and of mid shelf organisms in the oceanic region. The common and shared taxa indicate that advection, diffusion and dispersion processes generated a greater interaction between the Yucatan assemblage and the Tabasco-Campeche assemblage, and a lesser interaction between these and the oceanic community. In particular, the boundary between the YA and OA, TCA coincides with the type of sediment on the shelves, as they are calcareous on the Campeche Bank and terrigenous off Tabasco (Ayala-Castañares \& Gutiérrez-Estrada 1990).

Previous studies carried out in the region (Flores-Coto et al. 1988, 1993, 2009; Sanvicente-Añorve et al. 1998, Espinosa-Fuentes \& Flores-Coto 2004) have shown that there is an area where the oceanic and neritic populations mix. This area is located along the continental slope, but may extend towards the mid shelf or the oceanic area.

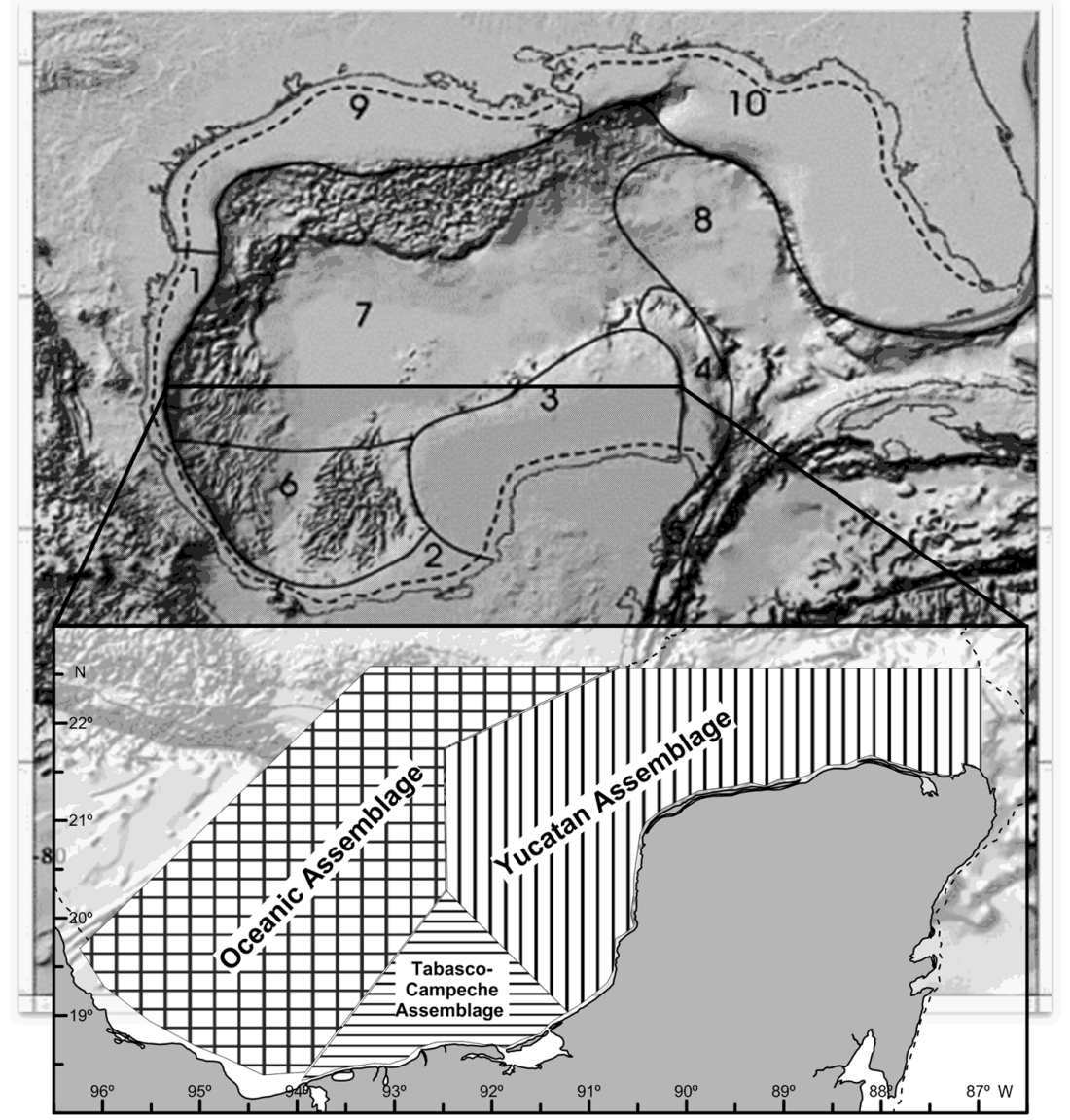

Figure 8. Comparative geographical areas in the hydrographical regionalization (Zavala-Hidalgo \& Fernández-Eguiarte 2006) and the assemblages defined in this study / Áreas geográficas comparativas en la regionalización hidrográfica (Zavala-Hidalgo \& Fernández-Eguiarte 2006) y las asociaciones definidas en el presente estudio 
However, the low number of oceanic taxa in neritic assemblages indicates a low influence of the oceanic community on the neritic communities. In addition, the Campeche Bank current always follows westward direction and may reach the Tabasco shelf, thus, it must have a greater influence on the oceanic and CampecheTabasco communities than the other way round, which explains the relatively high number of reef taxa in these communities, considering that the reefs are found only on the Campeche Bank (Carricat-Ganivet \& Horta-Puga 1993, Oliver et al. 2004). It may be that many larvae of reef dwelling parents use the westward currents to occupy the area of the Tabasco-Campeche communities as a nursery area and, as juveniles, return to the reefs on the Yucatan shelf and part of the Campeche shelf.

Important factors that generate boundaries between the assemblages are the gyres in Campeche Bay. The importance of the gyres regarding the distribution of planktonic organisms in the area may seem obvious, and has already been mentioned by Salas et al. (1998). However, the role that they play in Campeche Bay may be emphasized, as they limit the movement of coastal marine sediments towards the center of the Gulf bringing a recirculation within the bay (Gutiérrez-Estrada et al. 2003), and it may be assumed that this also happens with fish larvae and other planktonic organisms.

The gyre in Campeche Bay reaches the narrow shelves of Veracruz and western Tabasco, while it does not reach the inner Yucatan shelf or does so to a lesser degree, and it generates a boundary for the neritic waters at the continental slope off Tabasco and Campeche (Salas et al. 1992, 1998, Vidal-Lorandi et al. 2003, Signoret et al. 2006).

Boundaries are also generated by the freshwater discharges in the southern Gulf of Mexico. Several authors have recorded the presence of a front that may be detected in an almost permanent horizontal salinity gradient (Czitrom et al. 1986, Shirasago 1991, Monreal-Gómez et al. 1992).

The distribution of the salinity, temperature and turbidity values recorded in this study, though not establishing clear boundaries between the areas occupied by each assemblage, did present a close correspondence with them. In particular, the area with the lowest temperatures fitted well with the OA, and the area with the greatest turbidity, and to a lesser degree the lower salinity values, corresponded to the area occupied by the TCA. It is the combination of the circulation patterns, water properties and type of sediments which explains the region differences.

\section{Persistence of the assemblages}

The low number of shared taxa and the difference in the density of the more abundant taxa reflect the persistence of each assemblage in its respective area, where hydrodynamics play an important role, since the collision of currents and gyres generate hydrographic convergences, such as fronts, that act as barriers and restrict the movement of organisms from one area to another (Sabatés \& Olivar 1996).

No one factor by itself can be considered as determinant of the formation, location and persistence of any assemblage, it must be the sum of the partiality of each factor. Obviously, seasonal changes of water masses, currents, vertical mixing intensity of processes will determine the final pattern of the distribution of the assemblages (Alemany et al. 2006, Sabatés et al. 2007, Mühling et al. 2013).

Converging fronts overcome diffusive and advective flows (Miller 2002) and help maintain the assemblages within their areas. It must be understood that, notwithstanding that the larvae have a limited capacity to swim, they are not passive particles and thus 'ichthyoplanktonic assemblages may reflect larval behavioral responses to environmental signals' (Miller 2002).

It may be summarized that, apart from the different boundaries and interactions between the areas where the three assemblages were located, their formation was determined first by the habitat and spawning area of the adults, and next by the dominant physical factors that generate boundaries in each area and allow the formation of individual assemblages.

\section{ACKNOWLEDGMENTS}

Authors express their gratitude to anonymous reviewers for their comments and interest in this paper, we also thank the crew of the R/V Justo Sierra. The samples for this study were collected during the 'Monitoreo Ambiental del Sur del Golfo de México’, PEMEX Program, SGM11.

\section{LITERATURE CITED}

Araujo-Mendieta J, JE Aguayo-Camargo \& M GutiérrezEstrada. 2003. Provincias fisiográficas marinas recientes, su relación con la tectónica salina y la presencia de hidrocarburos en el suroeste del Golfo de México. En: Soto LA (ed). Agustín Ayala-Castañares. Universitario, impulsor de la investigación científica, pp. 209-223. Instituto de Ciencias del Mar y Limnología. Universidad Nacional Autónoma de México, México. 
Ayala-Castañares A \& M Gutiérrez-Estrada. 1990. Morfología y sedimentos superficiales de la plataforma continental frente a Tabasco y Campeche, México. Anales del Instituto de Biología, Universidad Nacional Autónoma de México 17: 163-190.

Bray JR \& JT Curtis. 1957. An ordination of the upland forest communities of southern Wisconsin. Ecological Monographs 27: 235-249.

Callejas-Jiménez M, M Santamaría del Angel, A González-Silvera, R Millán-Núnez \& $R$ CajalMedrano. 2012. Dynamic regionalization of the Gulf of Mexico based on normalized radiances (nLw) derived from MODIS-Aqua. Continental Shelf Research 37: 8-14.

Carricat-Ganivet JP \& G Horta-Puga. 1993. Arrecifes de coral de México. En: Salazar-Vallejo SI \& NE González (eds). Biodiversidad marina y costera de México, pp. 8092. Comisión Nacional de la Biodiversidad y CIQRO, México.

Czitrom SPR, F Ruíz, MA Alatorre \& AR Padilla. 1986. Preliminary study of a front in Bay of Campeche, Mexico. In: Nihoul JCJ (ed). Marine interfaces ecohydrodynamics, pp 301-311. Elsevier Oceanography Series, Amsterdam.

De la Cruz AG. 1994. Sistema para el análisis de comunidades ANACOM. Versión 3.0, 99 pp. Departamento de Pesquerías y Biología Marina. CICIMAR-IPN, La Paz.

Espinosa-Fuentes ML \& C Flores-Coto. 2004. Cross-shelf and vertical structure of ichthyoplankton assemblages in the continental shelf waters of the southern Gulf of Mexico. Estuarine Coastal and Shelf Science 59: 333-352.

Fahay MP. 2007. Early stages of fishes in the western North Atlantic Ocean (Davis strait, southern Greenland and Flemish cap to Cape Hatteras, 1696 pp. Norwest Atlantic Fisheries Organization, Dartmouth.

Falfán-Vázquez E, U Ordoñez-López \& M Ornelas-Roa. 2008. Variación espacial de larvas de lutjánidos y serránidos en la plataforma de Yucatán. Hidrobiológica 18: 69-76.

Flores-Coto C, L Sanvicente-Añorve, R Pineda-López \& MA Rodríguez. 1988. Composición, distribución y abundancia ictioplanctónica del sur del Golfo de México. Universidad y Ciencia 5(9): 65-84.

Flores-Coto C, F Zavala-García \& G Espinosa-Villagrán. 1993. Asociaciones ictioplanctónicas de la Bahía de Campeche, México (verano 1987). Facultad de Ciencias del Mar, Universidad Católica del Norte, Coquimbo, Chile. Serie Ocasional 2: 57-67.

Flores-Coto C, ML Espinosa-Fuentes, F Zavala-García \& L Sanvicente-Añorve. 2009. Ictioplancton del sur del Golfo de México. Un compendio. Hidrobiológica 19(1): 49-76.

Gutiérrez-Estrada M, JE Aguayo-Camargo \& J AraujoMendieta. 2003. Morfobatimetría y textura de los sedimentos de las provincias Banco de Campeche y Bahía de Campeche, suroeste del Golfo de México. En: Soto LA (ed). Agustín Ayala-Castañares. Universitario, impulsor de la investigación científica, pp. 189-208. Instituto de Ciencias del Mar y Limnología. Universidad Nacional Autónoma de México, México.

Marancik KE, LM Clough \& JA Hare. 2005. Cross-shelf and seasonal variation in larval fish assemblages on the southeast United States continental shelf off the coast of Georgia. Fishery Bulletin 103: 108-129.

Merino M. 1997. Upwelling on the Yucatan shelf: hydrographic evidence. Journal of Marine Systems 13: 101-121.

Miller TJ. 2002. Assemblages, communities and species interactions. In: Fuiman L \& RG Werner (eds). Fishery Science, pp. 183-205. Blackwell Science Limited, Oxford.

Monreal-Gómez MA, DA Salas de León, AR Padilla \& MA Alatorre. 1992. Hydrography and estimation of density currents in the southern part of the Bay of Campeche, Mexico. Ciencias Marinas 18: 115-133.

Muhling BA, RH Smith, L Vásquez-Yeomans, JT Lamking, EM Johns, L Carrillo, E Sosa-Cordero \& E Malca. 2013. Larval fish assemblages and mesoscale oceanographic structure along the Mesoamerican Barrier Reef system. Fisheries Oceanography 22: 409-428.

Oliver JM, Y Noordeloos, M Tan, N Nayan, C Foo \& F Shahriyah. 2004. Reefbase: A global information system on coral reefs. The WorldFish Center, Penang. <http:// reefbase.org>

Padilla-Pilotze AR, DA Salas de León \& MA MonrealGómez. 1990. Evidencia de un giro ciclónico en la Bahía de Campeche. Ciencias Marinas 16: 1-14.

Pérez-Brunius P, P García-Carrillo, J Dubranna, J Sheinbaum \& J Candela. 2013. Direct observations of the upper layer circulation in the southern Gulf of Mexico. Deep-Sea Research II 85: 182-194.

Portilla-Casillas J, VM Vidal-Lorandi, FV Vidal-Lorandi \& L Zambrano-Salgado. 2003. Simulaciones numéricas de la interacción y evolución de vértices en el sur del Golfo de México. En: Soto LA (ed). Agustín Ayala-Castañares. Universitario, impulsor de la investigación científica, pp. 131-137. Instituto de Ciencias del Mar y Limnología. Universidad Nacional Autónoma de México, México.

Rakocinski C, J Lyczkowski-Shultz \& S Richardson. 1996. Ichthyoplankton assemblages structure in Mississippi Sound as revealed by canonical correspondence analysis. Estuarine Coastal and Shelf Science 43: 237-257.

Richards JW. 2006. Early stages of Atlantic fishes. An identification guide for the western Central North Atlantic, 2640 pp. Taylor and Francis, Boca Raton.

Romanou A, EP Chassignet \& W Sturges. 2004. Gulf of Mexico circulation within a high-resolution numerical simulation of the North Atlantic Ocean. Journal of Geophysical Research 109: C01003 <doi:10.1029/ 2003JC001770> 
Sabatés A \& MP Olivar. 1996. Variation of larval fish distributions associated with variability in the location of a shelf-slope front. Marine Ecology Progress Series 135: 11-20.

Sabatés A, MP Olivar, J Salat, I Palomera \& F Alemany. 2007. Physical and biological processes controlling the distribution of fish larvae in the NW Mediterranean. Progress in Oceanography 74: 355-376.

Salas de León DA, MA Monreal-Gómez \& G ColungaEnríquez. 1992. Hidrografía y circulación geostrófica en el sur de la Bahía de Campeche. Geofísica Internacional 31(3): 315-323.

Salas de León DA, MA Monreal-Gómez, L SanvicenteAñorve \& C Flores-Coto. 1998. Influence de la circulation à long terme sur la répartition des organismes zooplanctoniques dans la Baie de Campeche, Mexique. Oceanologica Acta 21(1): 87-93.

Salmerón-García O, J Zavala-Hidalgo, A Mateos-Jasso \& R Romero-Centeno. 2011. Regionalization of the Gulf of Mexico from space-time chlorophyll-a concentration variability. Ocean Dynamics 61(4): <doi: 10.1007/s10236010-0368-1>

Sánchez-Velasco L \& C Flores-Coto. 1994. Larval fish assemblages at the Yucatán Shelf and in the Mexican Caribbean Sea, during the upwelling period (Spring 1985). Scientia Marina 58(4): 289-297.

Sanvicente-Añorve L, C Flores-Coto \& L Sánchez-Velasco. 1998. Spatial and seasonal patterns of larval fish assemblages in the southern Gulf of Mexico. Bulletin of Marine Science 62(1): 17-30.

Sanvicente-Añorve L, C Flores-Coto \& X Chiapa-Carrara. 2000. Temporal and spatial scales of ichthyoplankton distribution in the southern Gulf of Mexico. Estuarine Coastal and Shelf Sciences 51: 463-475.

Shirasago G. 1991. Hidrografía y análisis frontogenético en el sur de la Bahía de Campeche. Tesis de Maestría, Unidad Académica de los Ciclos Profesional y de Posgrado-CCH, Universidad Nacional Autónoma de México, México, 141 pp.
Signoret, M, MA Monreal-Gómez, J Aldeco \& DA Salas de León. 2006. Hydrography, oxygen saturation, suspended particulate matter and chlorophyll-a fluorescence in an oceanic region under fresh water influence. Estuarine Coastal and Shelf Science 69: 153-164.

Sutyrin GG, GD Rowe, LM Rothstein \& I Ginis. 2003. Baroclynic eddy interactions with continental slopes and shelves. Journal of Physical Oceanography 33(1): 283-291.

Vázquez de la Cerda AM, RO Reid, SF DiMarco \& AE Jochens. 2005. BOC circulation: an update. In: Sturges W \& A Lugo-Fernández (eds), Circulation in the Gulf of Mexico: Observations and models. Geophysical Monograph Series 161: 279-293. American Geophysical Union, Washington.

Vidal-Lorandi FV, VM Vidal-Lorandi, L Zambrano-Salgado \& J Portilla-Casillas. 2003. Simulaciones numéricas de la interacción y evolución de vértices, en el sur del Golfo de México. Afloramiento de agua en el Banco de Campeche durante mayo y junio de 1987. En: Soto LA (ed). Agustín Ayala-Castañares. Universitario, impulsor de la investigación científica, pp.155-159. Instituto de Ciencias del Mar y Limnología. Universidad Nacional Autónoma de México, México.

Zavala-Hidalgo J \& A Fernández-Eguiarte. 2006. Propuesta para la regionalización de los mares mexicanos desde el punto de vista de los procesos físicos: el Golfo de México. En: Córdova y Vázquez A, F Rosete-Vergés, G EnríquezHernández \& B Hernández de la Torre (eds). Ordenamiento ecológico marino. Visión temática de la regionalización, pp. 21-31. Instituto Nacional de Ecología-SEMARNAT, México.

Zavala-Hidalgo J, SL Morey \& JJ O'Brien. 2003. Seasonal circulation on the western shelf of the Gulf of Mexico using a high-resolution numerical model. Journal of Geophysical Research 108(C12), 3389 <http://dx.doi.org/10.1029/ 2003JC001879>

Received 23 September 2013 and accepted 7 July 2014

Editor: Claudia Bustos D. 